Journal of Engineering and Applied Sciences 14 (Special Issue 8): 10472-10481, 2019

ISSN: 1816-949X

(C) Medwell Journals, 2019

\title{
Synthesis, Characterization with Studing Anti Convulsant Activity of Some New Resins by Free Radical Polymerization Starting from Chalcone Derivatives
}

\author{
Iman Mehdi Mohammed Hasan \\ Department of Chemistry, College of Science for Women, University of Baghdad, Baghdad, Iraq
}

\begin{abstract}
A new series of chalcone derivatives was synthesized then polymerized theirs due to resins. Starting from (E)-3-(benzo[d] [1, 3] dioxol-5-yl)-1-(4-hydroxyphenyl) prop-2-en-1-one [1] which reacts with di bromo ethan preperated $\left[\mathrm{C}_{2}\right]$ then reacted with secondary amines(piperidine, morpholine, piperazine, 4-methyl piperidine) to prepare $\left[\mathrm{C}_{3}-\mathrm{C}_{6}\right]$ as monomers which polymerized using AIBN initiator due to resins $\left[\mathrm{C}_{7}-\mathrm{C}_{10}\right]$. All proposed structure were supported by FTIR, some derivatives evaluated by $\mathrm{H}^{1}$-NMR, elemental analysis, thermal analysis (TGA, DSC) and evaluated for anticonvulsant activity by MES method, most of derivatives were found to be more or comparable potent than the reference standard drug.
\end{abstract}

Key words: Chalcons derivatives, Claisen schmidt reaction, free radical polymerization, comparable, drug, anticonvulsant activity

\section{INTRODUCTION}

Chalcones are well known inter mediates for synthesizing various heterocyclic compounds (Pasquale et al., 2012). The compounds with be back bone of chalcones have been reported to posses various biological activities (Asiri and Khan, 2012) such as anti-inflammatory (Muralidharan et al., 2018), antiplatelet (Asiri and Khan, 2012), antimalarial (Yadav et al., 2012), antioxidant (Lahsasni et al., 2014), anticonvulsant (Beyhan et al., 2017), anticancer, inhibition (El-Messery et al., 2018) of chemical mediators release, inhibition of leukotriene $\left(B_{4}\right)$, inhibition of tyrosin as and inhibition of aldose reductase activitys (Zhuang et al., 2017), the discovery of derivatives was also based on the rational considerations of pathophysiological mechanism of epileptic syndrome. Hence, the endeavor of the century is to develop antiepileptic drugs with $100 \%$ efficiency, safety and tolerability.

\section{MATERIALS AND METHODS}

General: Melting points were determined on Gallen kamp, melting point apparatus and were uncorrected. FTIR spectra of the compounds were recorded on a (SHIMADZU) FTIR. 8300 Spectrometer as KBR-disc, ${ }^{1} \mathrm{H}-\mathrm{NMR}$ spectra were recorded at 200.13-50.32 MHz, respectively using Tetra Methyl Silane (TMS) as an internal standard, DMSO as a solvent. Elemental analysis were run using a Perkin-Elmer RE 2400 (CHN) analyzer, thermal stability (TGA\&DSC), MES method.
All analysis were performed in: University of Baghdad College of Education for Pure Sciences Ibn-Al-Haitham Central Service Laboratory and College of Pharmacy Department of Pharmacognosy.

All the chemical used were supplied by (Merk, Fluka and $\mathrm{BDH}$ ) chemicals, the solvents purified by distillation and dried with calcium chloride.

Measurement and techniques: The purity of products were investigated by (TLC) technique by using a mixture of benzene-ethanol $(5: 5 \mathrm{v} / \mathrm{v})$ as elute and iodine chamber for spot location.

\section{Differential scanning calorimetry and thermal} gravemetric:

Analysis: Differential Scanning Calorimetry (DSC) and Thermal Gravemetric Analysis (TGA) was carried out using LINSEIS (DSC), equipped with an internal cooler 2P-cooling accessory and some of them were performed in Chemistry Department, College of Education for Pure Sciences\Ibn AL-Haitham [The Central Service Laboratory].

Synthesis of (E)-1-(4-hydroxyphenyl)-3-(2, 3, 4a, 8atetrahydrobenzo $[b][1,4]$ dioxine-2-yl) prop-2-en-1one $\left[C_{1}\right]$ (Mohammed, 2015): A mixture of benzo [d] [1, 3] dioxole-5-carbaldehyde $(0.035 \mathrm{~mol})$ with 1-(4-hydroxy phenyl) ethanone (0.045) in $10 \mathrm{~mL}$ absolute ethanol of $20 \% \mathrm{NaOH}$ was stirred on ice water bath at $3 \mathrm{~h}$. The mixture kept stirred at room temperature over night then poured on to ice cold water and acidified with dilute HCL, filterered, crystallized from ethanol, m.p $\left(225-227^{\circ} \mathrm{C}\right)$, yield $90 \%$, color pale brown. 
J. Eng. Applied Sci., 14 (Special Issue 8): 10472-10481, 2019

Table 1: Dapcited physical properties for [1-10]

\begin{tabular}{llllll}
\hline Comp No. & Molecular formula & MP $\left({ }^{\circ} \mathrm{C}\right)$ & Colour & Yield (\%) & Purification solvent \\
\hline 1 & $\mathrm{C}_{16} \mathrm{H}_{12} \mathrm{O}_{4}$ & $225-227$ & Pale brown & 90 & Ethanol \\
2 & $\mathrm{C}_{18} \mathrm{H}_{15} \mathrm{O}_{4} \mathrm{Br}$ & $229-231$ & Brown & 85 & Ethanol \\
3 & $\mathrm{C}_{23} \mathrm{H}_{25} \mathrm{O}_{4} \mathrm{~N}$ & $119-121$ & Brown & 85 & Acetone \\
4 & $\mathrm{C}_{22} \mathrm{H}_{23} \mathrm{O}_{5} \mathrm{~N}$ & $115-117$ & Brown & 80 & Acetone \\
5 & $\mathrm{C}_{22} \mathrm{H}_{23} \mathrm{O}_{4} \mathrm{~N}_{2}$ & $109-111$ & Brown & 80 & Acetone \\
6 & $\mathrm{C}_{23} \mathrm{H}_{26} \mathrm{O}_{4} \mathrm{~N}$ & $105-107$ & Brown & 75 & Acetone \\
7 & $\mathrm{C}_{23} \mathrm{H}_{25} \mathrm{O}_{4} \mathrm{~N}$ & Oily & Brown & 65 & DMF \\
8 & $\mathrm{C}_{22} \mathrm{H}_{23} \mathrm{O}_{5} \mathrm{~N}$ & Oily & Brown & 70 & DMF \\
9 & $\mathrm{C}_{22} \mathrm{H}_{23} \mathrm{O}_{4} \mathrm{~N}_{2}$ & oily & Brown & 70 & DMF \\
10 & $\mathrm{C}_{23} \mathrm{H}_{26} \mathrm{O}_{4} \mathrm{~N}$ & oily & Brown & DMF \\
\hline
\end{tabular}

Synthesis of (E)-3-(benzo [d] [1, 3] dioxol-5-yl)-1(4-bromoethoxy) phenyl) prop-2-en-1-one $\left[\mathrm{C}_{2}\right]$ (Ohkubo et al., 2016): Sodium hydroxide (0.7 g) was dissolved in warm absolute ethanol $(14 \mathrm{~mL})$, the solution stirred for (1 h), [ $\left.\mathrm{C}_{1}\right]$ (1.7 g, $\left.0.01 \mathrm{~mol}\right)$ dissolved in absolute ethanol $(10 \mathrm{~mL})$ then the first prepared solution is add to second solution drop wise, the mixture was stirred for (15 min), (0.05 mol) from dibromo ethan add to that mixtures which refluxed for $(6 \mathrm{~h})$, completion of the reaction confirmed by TLC, cooled, filter, dried and purified by recrystallization from absolute ethanol, $\mathrm{mp}$ (229-231 $\left.{ }^{\circ} \mathrm{C}\right)$, yield $85 \%$, color brown in Table 1.

General synthesis of monomers $\left[\mathrm{C}_{3}-\mathrm{C}_{6}\right]$ (Chen et al., 2018): A $250 \mathrm{~mL}$ necks mixture of $\left[\mathrm{C}_{2}\right]$ with $(30 \mathrm{~mL})$ mixture of (acetone with DMF) (v:v/1:1) and [piperidine, morpholine, piperazine, 4-methyl piperidine) which add, the reaction refluxed for $(4 \mathrm{~h})$ confirmed by (TLC) the mixture cooled and purified by recrystallization from acetone, $\mathrm{mp}\left(219-221^{\circ} \mathrm{C}\right)$, yield $85 \%$ for $\left[\mathrm{C}_{3}\right], \mathrm{mp}$ $\left(115-117^{\circ} \mathrm{C}\right)$, yield $80 \%$ for $\left[\mathrm{C}_{4}\right]$, mp $\left(109-111^{\circ} \mathrm{C}\right)$, yield $80 \%$ for $\left[C_{5}\right]$, mp $\left(105-107^{\circ} \mathrm{C}\right)$, yield $75 \%$ for $\left[C_{6}\right]$, respectively in Table 1 .

General synthesis of resins $\left[\mathrm{C}_{7}-\mathrm{C}_{10}\right]$ (VictoriaValenzuela et al., 2018): The polymerization of these monomers was carried out in by using AIBN as initiator. A solution of the monomers $(0.01 \mathrm{~mol})$ in DMF $(25 \mathrm{~mL})$ and $(5 \mathrm{~g})$ of initiater were mixed in round bottle. The mixture was heated in oil bath $\left(50-70^{\circ} \mathrm{C}\right)$. After $(2 \mathrm{~h})$ the contents in flask were poured into a large amount of (DMF) to precipitate the resins and evaporated under vacume, purity by TLC in Table 1.

\section{RESULTS AND DISCUSSION}

Considerable interest have been expressed in synthesis of chalcone compound in recent year due to their industrial and biological importance, starting from $\left[\mathrm{C}_{1}\right]$

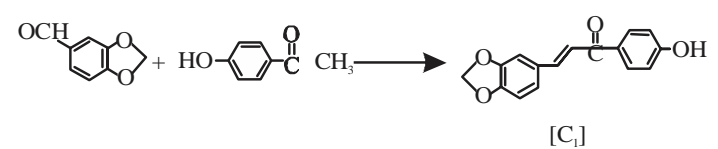

Scheme-1-Synthesis of chalcone $\left[\mathrm{C}_{1}\right]$
The FTIR spectrum Williams and Felming (1986) $\left[\mathrm{C}_{1}\right]$ showed the strong streaching (3454-3302 $\mathrm{cm}^{-1}$ ) due to $(\mathrm{OH})$ groups, $\left(1693 \mathrm{~cm}^{-1}\right)$ for $(\mathrm{C}=\mathrm{O})$, (1260-1045 $\left.\mathrm{cm}^{-1}\right)$ for (C-O-C), $\left(830 \mathrm{~cm}^{-1}\right)$ for (1,4-disubst), (3072 $\left.\mathrm{cm}^{-1}\right)$ for (Ar-H), $\left(1420 \mathrm{~cm}^{-1}\right)$; for (C-N); ${ }^{1} \mathrm{H}-\mathrm{NMR}$ (DMSO-d6) $\delta$ : (7.4-7.9 ppm) due to (Ar-H), (10.3 ppm) due to $(\mathrm{H}, \mathrm{OH}),(2.4-3.4 \mathrm{ppm})$ for $\left(\mathrm{H}, \mathrm{CH}_{2}\right)$, elemental analysis $(\mathrm{CHN})$ for compound [1] were fitted according to Table 3 . Therefore, $\left[\mathrm{C}_{2}\right]$ prepared by the condensation of the corresponding $\left[\mathrm{C}_{1}\right]$ with dibromo ethane in refluxing ethanol.

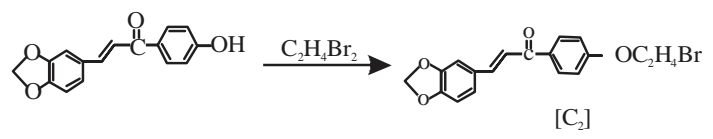

Scheme-2-Synthesis of $\left[\mathrm{C}_{2}\right]$

The FTIR, Williams and Felming (1986) spectrum $\left[\mathrm{C}_{2}\right]$ showed the strong bands $\left(2839 \mathrm{~cm}^{-1}\right)$ for $\left(\mathrm{CH}_{2}\right)$ combined with disappearance of stretching bands strong bands (3454-3302 $\left.\mathrm{cm}^{-1}\right)$ for $(\mathrm{OH}),\left(1693 \mathrm{~cm}^{-1}\right)$ due to $(\mathrm{C}=\mathrm{O})$ and $\left(740 \mathrm{~cm}^{-1}\right)$ absorption bands for $(\mathrm{Br})$; ${ }^{1} \mathrm{H}-\mathrm{NMR}$ (Williams and Felming, 1986) (DMSO-d6) $\delta$ : (7.5-8.48 ppm) for (Ar-H), (2.3-4.3 ppm) $\left(\mathrm{H}, \mathrm{CH}_{2}\right)$. Elemental analysis for $\left[\mathrm{C}_{2}\right]$ were fitted according to the Table 3.

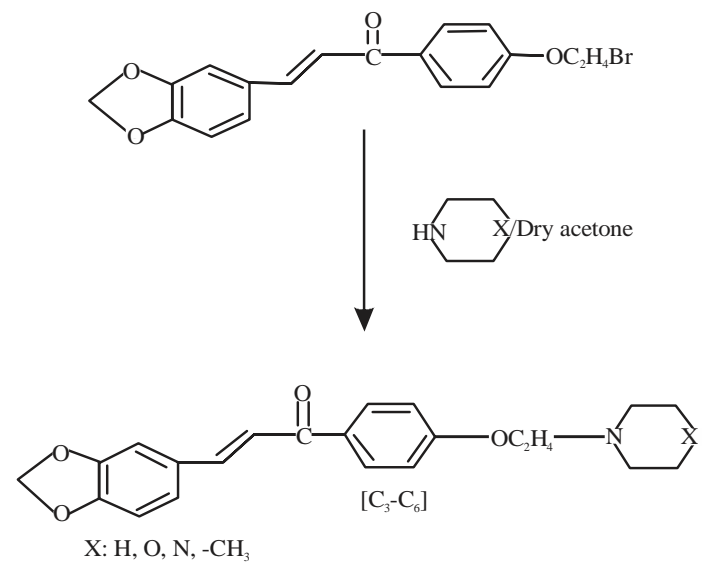

Scheme-3-Synthesis of $\left[\mathrm{C}_{3}-\mathrm{C}_{6}\right]$ 
J. Eng. Applied Sci., 14 (Special Issue 8): 10472-10481, 2019

Table 2: FTIR spectral data of [1-10]

\begin{tabular}{lllll}
\hline Comp No. & $\mathrm{VCH}_{2}$ & $\mathrm{VC}-\mathrm{O}-\mathrm{C}$ & $\mathrm{VC}=\mathrm{O}$ & Others \\
\hline 1 & $2990-2855$ & $1260-1045$ & 1693 & $\mathrm{~V}(\mathrm{OH}): 3454-3302, \mathrm{~V}(=\mathrm{C})(==\mathrm{CH}): 3072$ \\
2 & 2839 & $1200-1212$ & 1635 & $\mathrm{~V}(\mathrm{Br}): 740 ; \mathrm{VC}=\mathrm{C}(1597), \mathrm{V}(=\mathrm{CH}): 3028$ \\
3 & $2982-2854$ & $1192-1100$ & 1700 & $\mathrm{~V}(=\mathrm{CH})(3061)$ \\
4 & $2980-2975$ & $1226-1168$ & 1691 & $\mathrm{~V}(=\mathrm{CH})(3055)$ \\
5 & $2958-2834$ & 1202 & 1689 & $\mathrm{~V}(=\mathrm{CH})(3065)$ \\
6 & - & 1221 & 1702 & $\mathrm{~V}(=\mathrm{CH})(3097)$ \\
7 & $2931-2873$ & $1201-1205$ & 1691 & $\mathrm{~V}(=\mathrm{CH})(3095)$ \\
8 & $2980-2870$ & $1228-1222$ & 1735 & $\mathrm{~V}(=\mathrm{CH})(3049)$ \\
9 & $2935-2870$ & $1235-1228$ & 1699 & $\mathrm{~V}(=\mathrm{CH})(3009)$ \\
10 & $2918-2850$ & $1268-1238$ & 1683 & $\mathrm{~V}(=\mathrm{CH})(3037)$ \\
\hline
\end{tabular}

Table 3: ${ }^{1} \mathrm{H}-\mathrm{NMR}$ spectral data for some compound

\begin{tabular}{ll}
\hline Comp. No & H-NMR/ppm \\
\hline 1 & Ar-H $(\delta=7.4-7.9 \mathrm{ppm}),(2.4-3.4 \mathrm{ppm})$ for $\left(\mathrm{H}, \mathrm{CH}_{2}\right),(10.3$ \\
& $\operatorname{ppm})$ for $(\mathrm{H}, \mathrm{OH})$ \\
2 & $\mathrm{Ar}-\mathrm{H}(7.5-8.4 \mathrm{ppm}),(2.3-4.3 \mathrm{ppm})$ for $\left(\mathrm{H}, \mathrm{CH}_{2}\right)$ \\
6 & $\mathrm{Ar}-\mathrm{H}(\delta: 7.03 \mathrm{ppm}),(2.4-3.5 \mathrm{ppm})$ for $(\mathrm{H}, \mathrm{CH})$ \\
10 & $\mathrm{Ar}-\mathrm{H}(6.7-7.7 \mathrm{ppm}),(2.07-3.37 \mathrm{ppm})$ for $\left(\mathrm{H}, \mathrm{CH}_{2}\right)$ \\
\hline
\end{tabular}

FTIR, Williams and Felming (1986) spectrum [ $\left.\mathrm{C}_{3}\right]$ of stretching vibration is more bands at (2982-2854 $\left.\mathrm{cm}^{-1}\right)$ for $\left(\mathrm{CH}_{2}\right)$ and strong vibration at $\left(1226-1168 \mathrm{~cm}^{-1}\right)$ for (C-O-C), $\left(3061 \mathrm{~cm}^{-1}\right.$ ) for (Ar-H), $\left(1700 \mathrm{~cm}^{-1}\right)$ for $(C=O)$, elemental analysis for $\left[C_{3}\right]$ were fitted according to Table 2 and 3.

FTIR (Williams and Felming, 1986) spectrum $\left[\mathrm{C}_{6}\right]$ showed the bands of $\left(3061 \mathrm{~cm}^{-1}\right)$ for $(\mathrm{Ar}-\mathrm{H})$ and $\left(1702 \mathrm{~cm}^{-1}\right)$ for $(\mathrm{C}=\mathrm{O})$, H-NMR $\left(\right.$ DMSO-d $\left._{6}\right) \delta$ : (2.4-3.5 ppm) for $\left(\mathrm{H}_{-} \mathrm{CH}_{2}\right),(7.03 \mathrm{ppm})$ due to $(\mathrm{Ar}-\mathrm{H})$, elemental analysis for $\left[\mathrm{C}_{6}\right]$ were fitted according to Table 3. Therefor, $\left[\mathrm{C}_{3}-\mathrm{C}_{6}\right]$ using as monomers which polymerization by AIBN initaitors in $(50-70)^{\circ} \mathrm{C}$ due to $\left[\mathrm{C}_{7}-\mathrm{C}_{10}\right]$ resins:

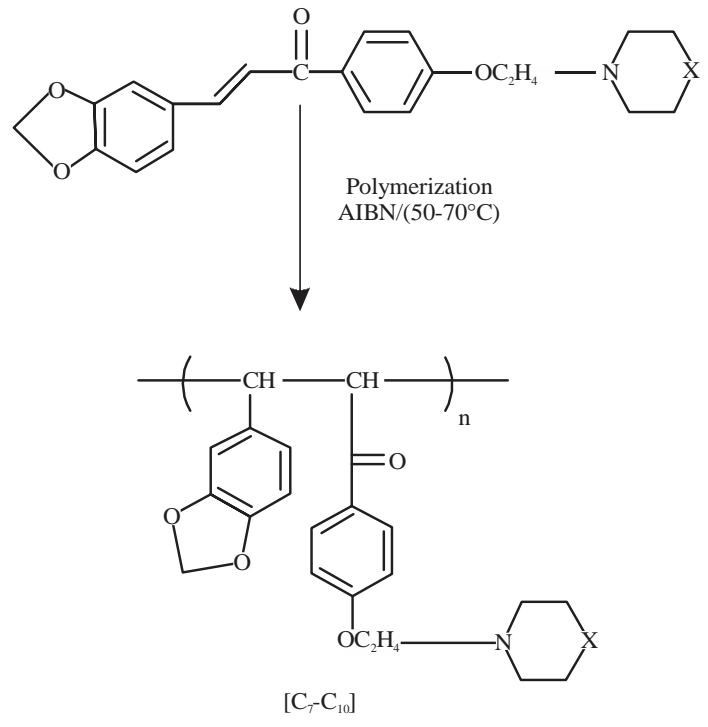

$\mathrm{X}: \mathrm{H}, \mathrm{O}, \mathrm{N},-\mathrm{CH}_{3}$

Scheme-4-Synthesis of $\left[\mathrm{C}_{7}-\mathrm{C}_{10}\right]$
Table 4: Depacited elemental analysis (CHN) for some compounds

\begin{tabular}{llll}
\hline & & $(\mathrm{CHN})$ analysis calculated (found) & \\
Comp No. & $\mathrm{C}(\%)$ & $\mathrm{H}(\%)$ & $\mathrm{N}(\%)$ \\
\hline 1 & $76(77.5)$ & $4.76(5.91)$ & - \\
2 & $57.6-59.0$ & $4-5.5$ & - \\
3 & $39.70-40.5$ & $5.59(6.60)$ & $21.05-22.5$ \\
8 & $69.29(70.5)$ & $6.04(6.96)$ & $3.67(4.45)$ \\
9 & $69.65(70.55)$ & $6.06(7.11)$ & $7.39(8.8)$ \\
10 & $72.63(73.88)$ & $6.84(7.91)$ & $3.68(4.77)$ \\
\hline
\end{tabular}

The FTIR spectrum $\left[\mathrm{C}_{8}\right]$ showed the bands $\left(3049 \mathrm{~cm}^{-1}\right)$ for $(\mathrm{Ar}-\mathrm{H}),\left(2980-2870 \mathrm{~cm}^{-1}\right)$ for $\left(\mathrm{CH}_{2}\right)$ and $\left(1735 \mathrm{~cm}^{-1}\right)$ due to $(\mathrm{C}=\mathrm{O})$, FTIR spectrum for $\left[\mathrm{C}_{8}\right]$ obtained $\left(3037 \mathrm{~cm}^{-1}\right)$ for $(\mathrm{Ar}-\mathrm{H}),\left(1683 \mathrm{~cm}^{-1}\right)$ due to $(\mathrm{C}=\mathrm{O}), \mathrm{H}-\mathrm{NMR}\left(\mathrm{DMSO}_{\mathrm{d}}\right.$ ) $\delta$ : (6.7-7.7 ppm) for $(\mathrm{Ar}-\mathrm{H})$, (2.07-3.37 ppm) for $(\mathrm{H}, \mathrm{CH})$, element analysis for $\left[\mathrm{C}_{10}\right]$ were fitted according to Table 3.

All these steps were summarized in Schemes (1-4) physical properties of all mentioned and other details [FTIR, elemental analysis, anticonvulsant activity (TGA \&DSC) analysis, ${ }^{1} \mathrm{H}-\mathrm{NMR}$, all data are listed in Table 1-6, respectively, curing thermal stability of some compounds were evaluated by using (TGA\&DSC) Table 4 are clearly show the temperature rate belong to different type dissociated for derivatives (Fig. 1-14).

Acute toxicity study: The tested compounds were administered intra peritoneally at different dose levels in separate groups of after ( $24 \mathrm{~h}$ ) of the drug administration of the percent mortality in each group was observed, Approximate Lethal Dose $\left(\mathrm{ALD}_{50}\right)$ was calculated by karbers method ( $>300 \mathrm{mgkg}^{-1}$ ).

Anti convulsant activity: Animal were weighted and numbered then divided in two groups each consisting of (2-3) mices, one group were used as control and the other for sample compound treatment.

The comeal electrodes were placed on the comea of animal and the prescribed current were applied. The reading of different stages of convulsant. The sample compound were injected intra peritoneally to group (2-3) mices. 
J. Eng. Applied Sci., 14 (Special Issue 8): 10472-10481, 2019

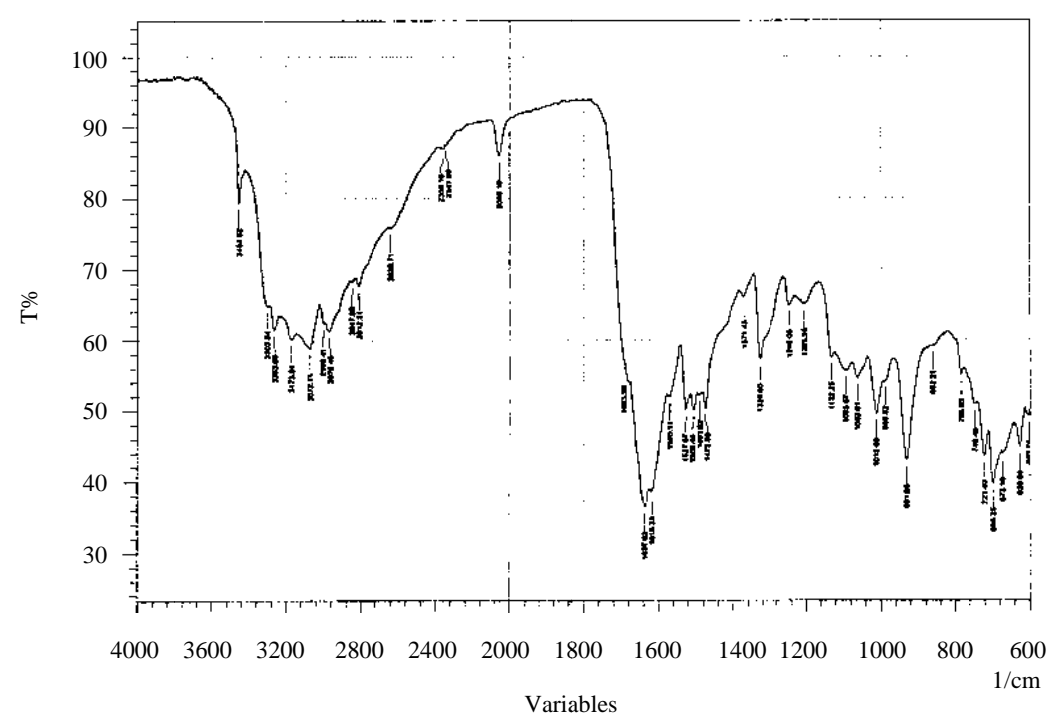

Fig. 1: FT-IR of $\left[\mathrm{C}_{1}\right]$

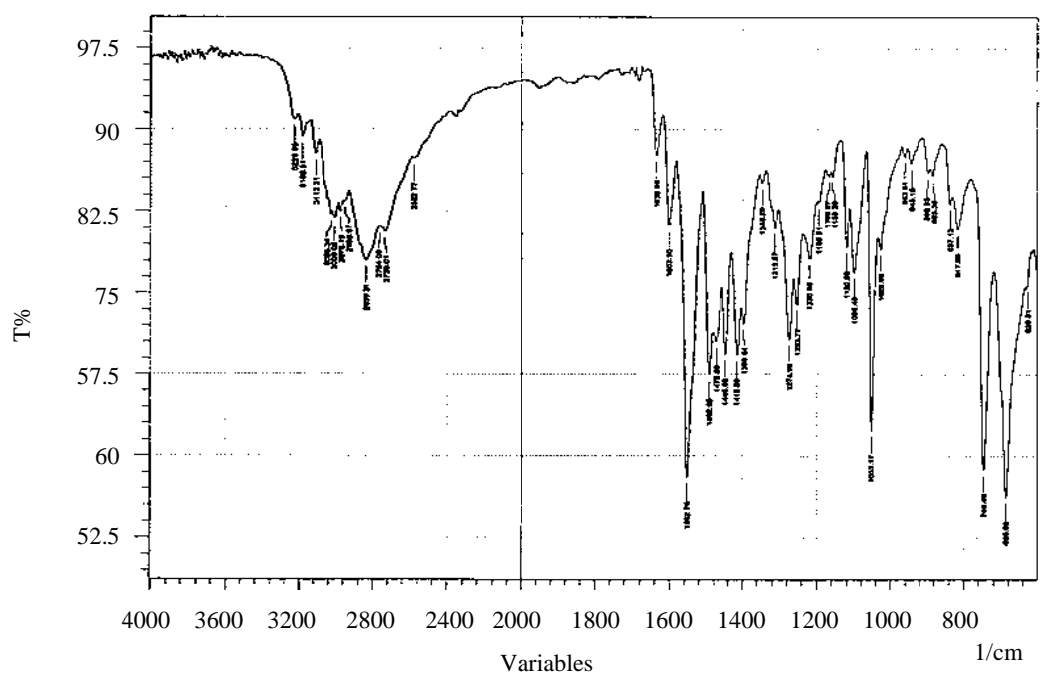

Fig. 2: FT-IR of $\left[\mathrm{C}_{2}\right]$

Table 5: Thermal behavior data for synthesized resins $\left[\mathrm{C}_{7}-\mathrm{C}_{10}\right]$

\begin{tabular}{|c|c|c|c|}
\hline Comp No. & \multicolumn{2}{|l|}{ On set point } & $\mathrm{T}_{\mathrm{g}}$ \\
\hline 7 & \multicolumn{2}{|l|}{298.2} & 304.1 \\
\hline 8 & \multicolumn{2}{|c|}{ 51.9, 106.7, 321.1} & $58.4,112$. \\
\hline 9 & \multicolumn{2}{|c|}{139.6} & 290.4 \\
\hline 10 & \multicolumn{2}{|c|}{$44.9,269.7$} & $47.7,272$. \\
\hline \multicolumn{4}{|c|}{$\begin{array}{l}\text { On set temperature recorded by TGA, DSC; The midpoint temperature } \\
10^{\circ} \mathrm{C} / \mathrm{min} \text { ) was defined asTg; Residual weight percentage at } 600^{\circ} \mathrm{C} \text { un }\end{array}$} \\
\hline \multicolumn{4}{|c|}{ Table 6: Extensor phase duration of systhesized title resins (sec) } \\
\hline Comp. No & Dose: $\mathrm{mg} / \mathrm{kg}$ & Mean \pm SEM & Protection (\%) \\
\hline$\overline{\text { Control (DMSO) }}$ & - & $8.700 \pm 0.07$ & - \\
\hline Phenytion (STD) & 24 & $1.600 \pm 0.05$ & 85 \\
\hline $\mathrm{C}_{7}$ & 28 & 2.015 & 75 \\
\hline $\mathrm{C}_{8}$ & 29 & 1.900 & 87 \\
\hline $\mathrm{C}_{9}$ & 30 & 2.980 & 77 \\
\hline $\mathrm{C}_{10}$ & 30 & 1.600 & 85 \\
\hline
\end{tabular}

\begin{tabular}{lc} 
Off set point & Char (\%) \\
\hline 310.2 & 82 \\
$78.9,123.9,328.9$ & 84 \\
525.6 & 80 \\
$64.1,295.0$ & 80
\end{tabular}

$\frac{64.1,295.0}{80}$ 
J. Eng. Applied Sci., 14 (Special Issue 8): 10472-10481, 2019

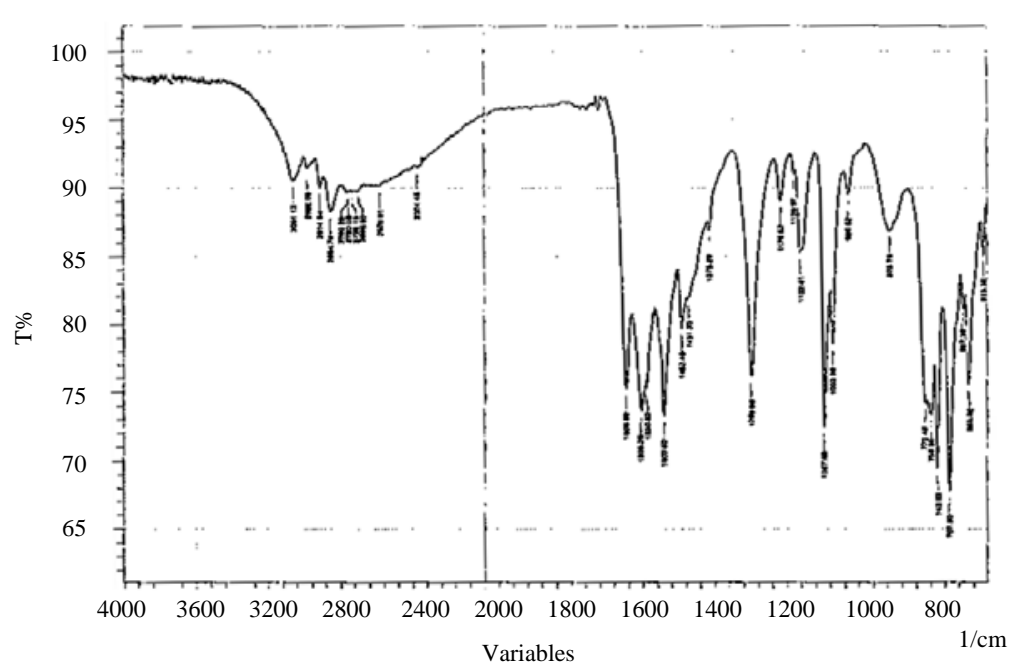

Fig. 3: FT-IR of $\left[\mathrm{C}_{3}\right]$

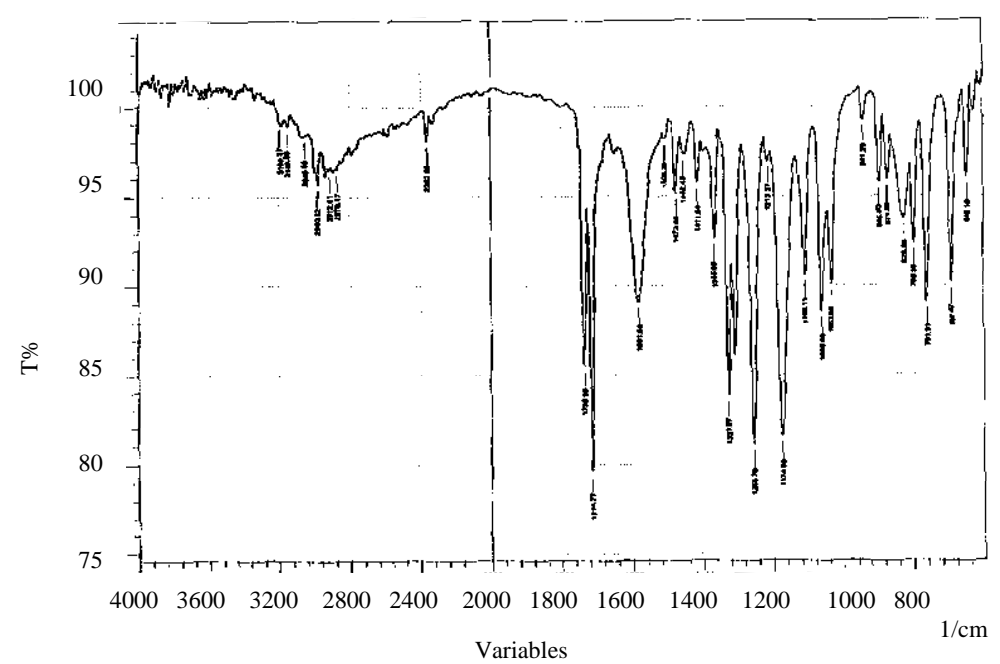

Fig. 4: FT-IR of $\left[\mathrm{C}_{6}\right]$

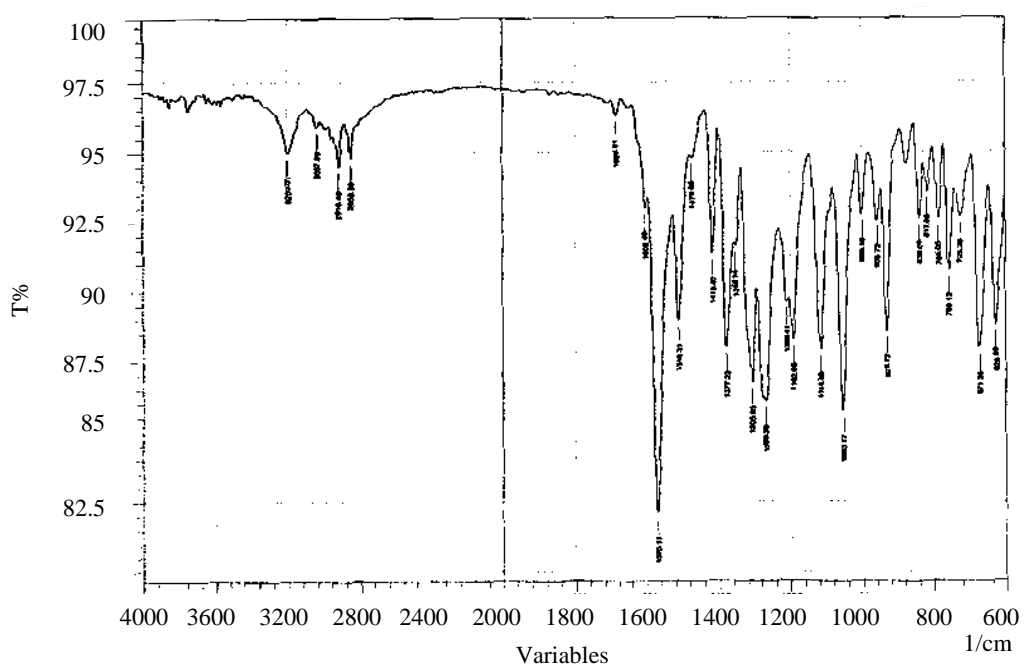

Fig. 5: FT-IR of $\left[\mathrm{C}_{8}\right]$ 
J. Eng. Applied Sci., 14 (Special Issue 8): 10472-10481, 2019

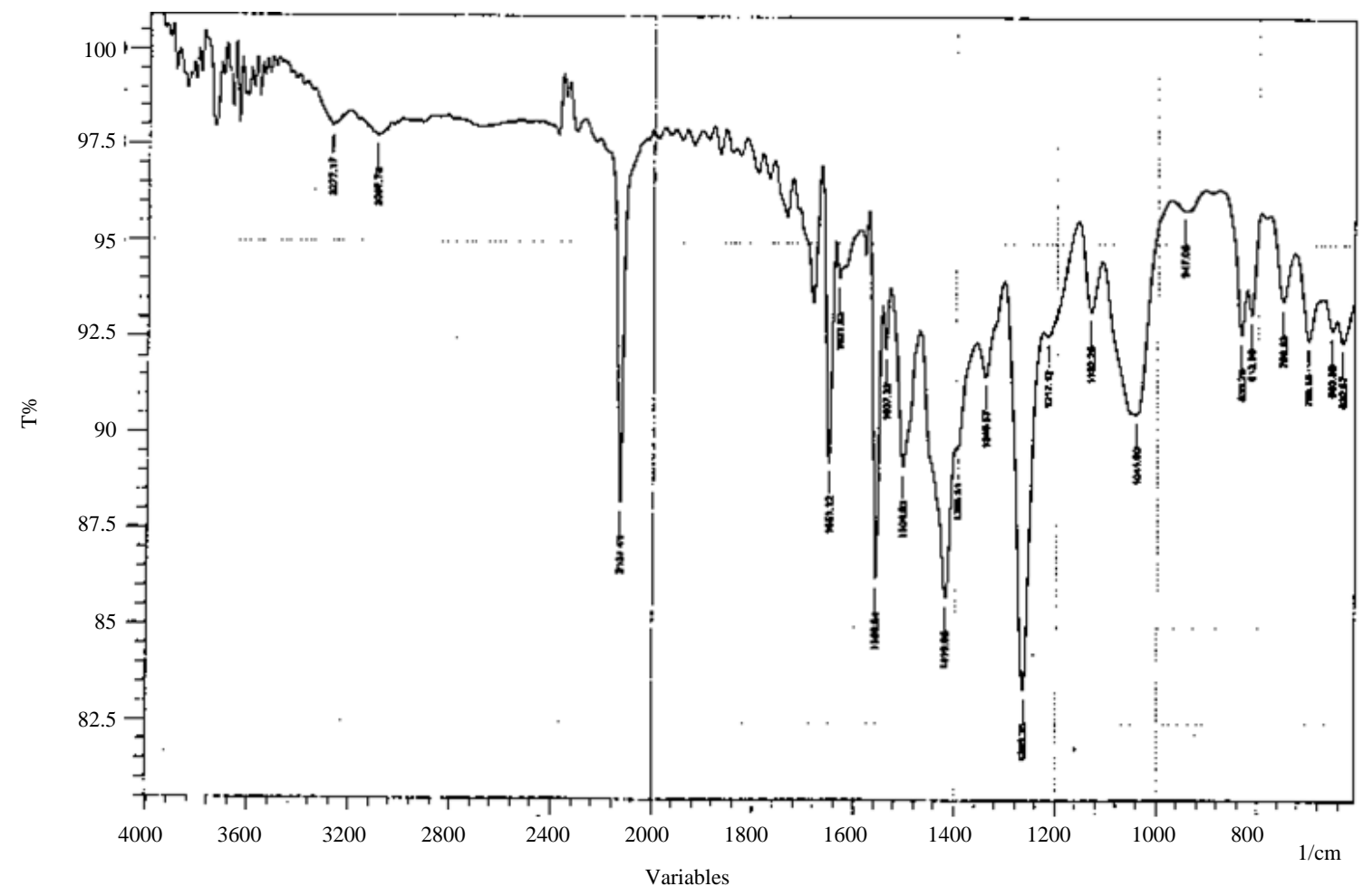

Fig. 6: FT-IR of $\left[\mathrm{C}_{10}\right]$

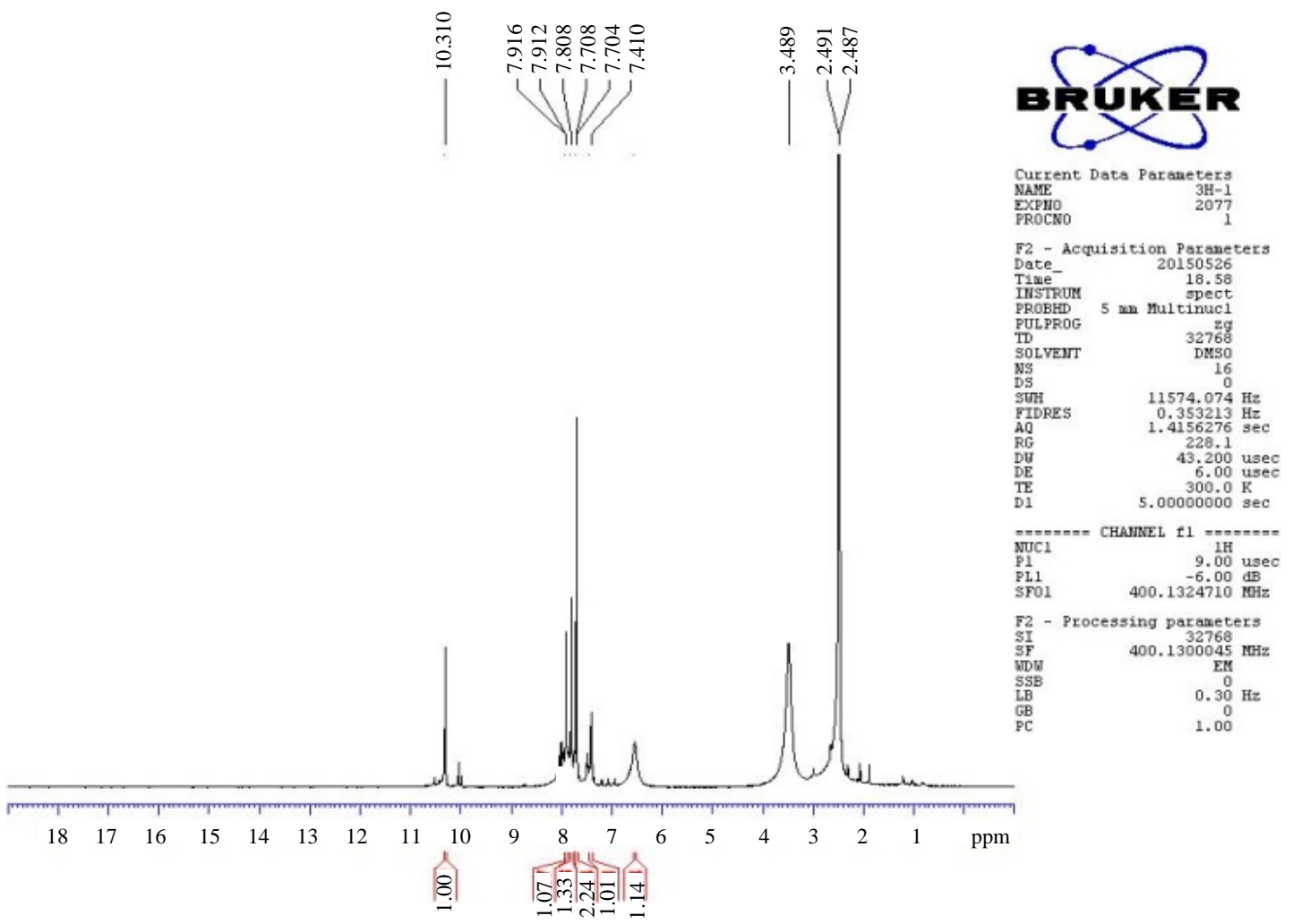

Fig. 7: H-NMR spectrum of $\left[\mathrm{C}_{1}\right]$ 


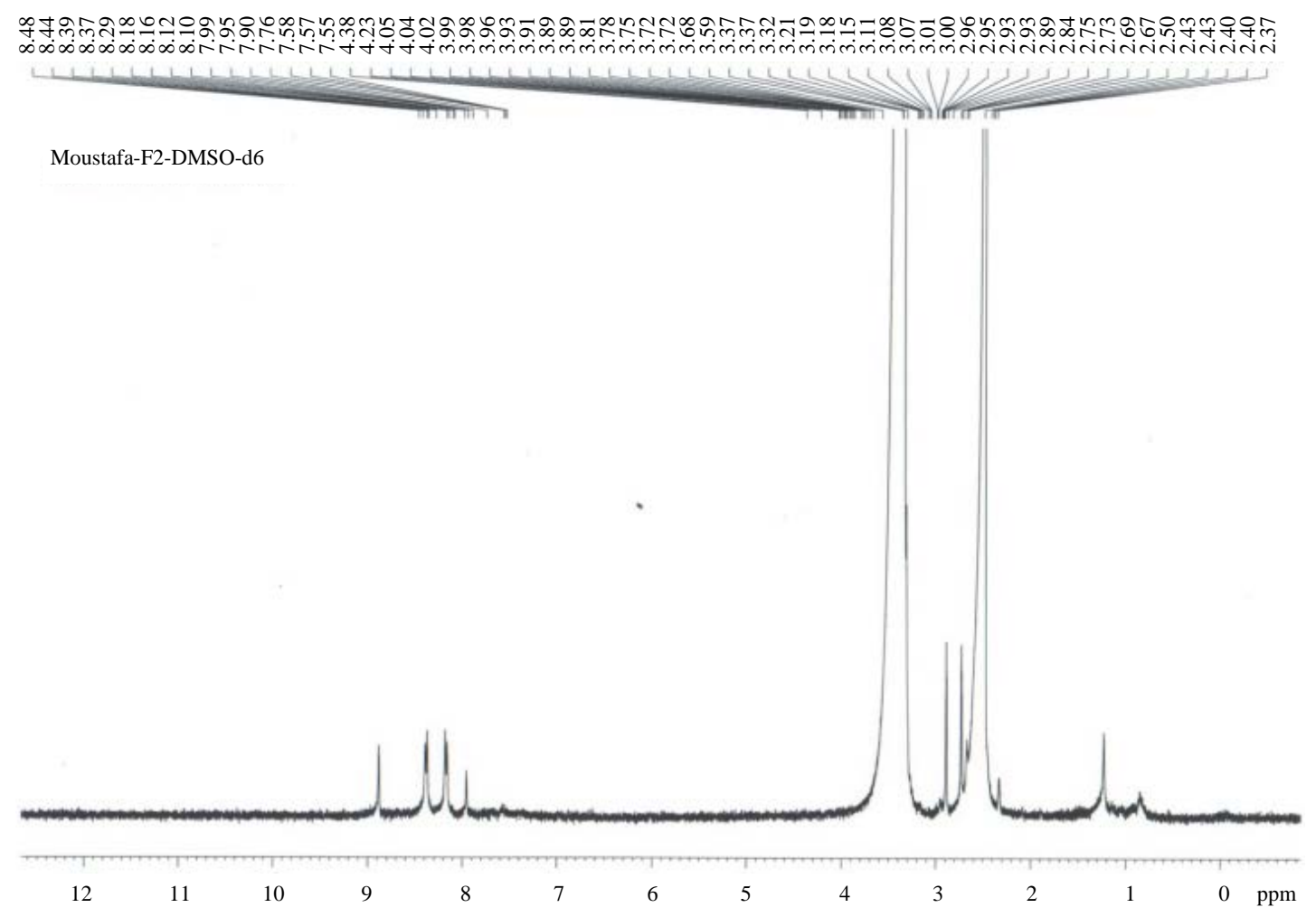

Fig. 8: H-NMR spectrum of $\left[\mathrm{C}_{2}\right]$

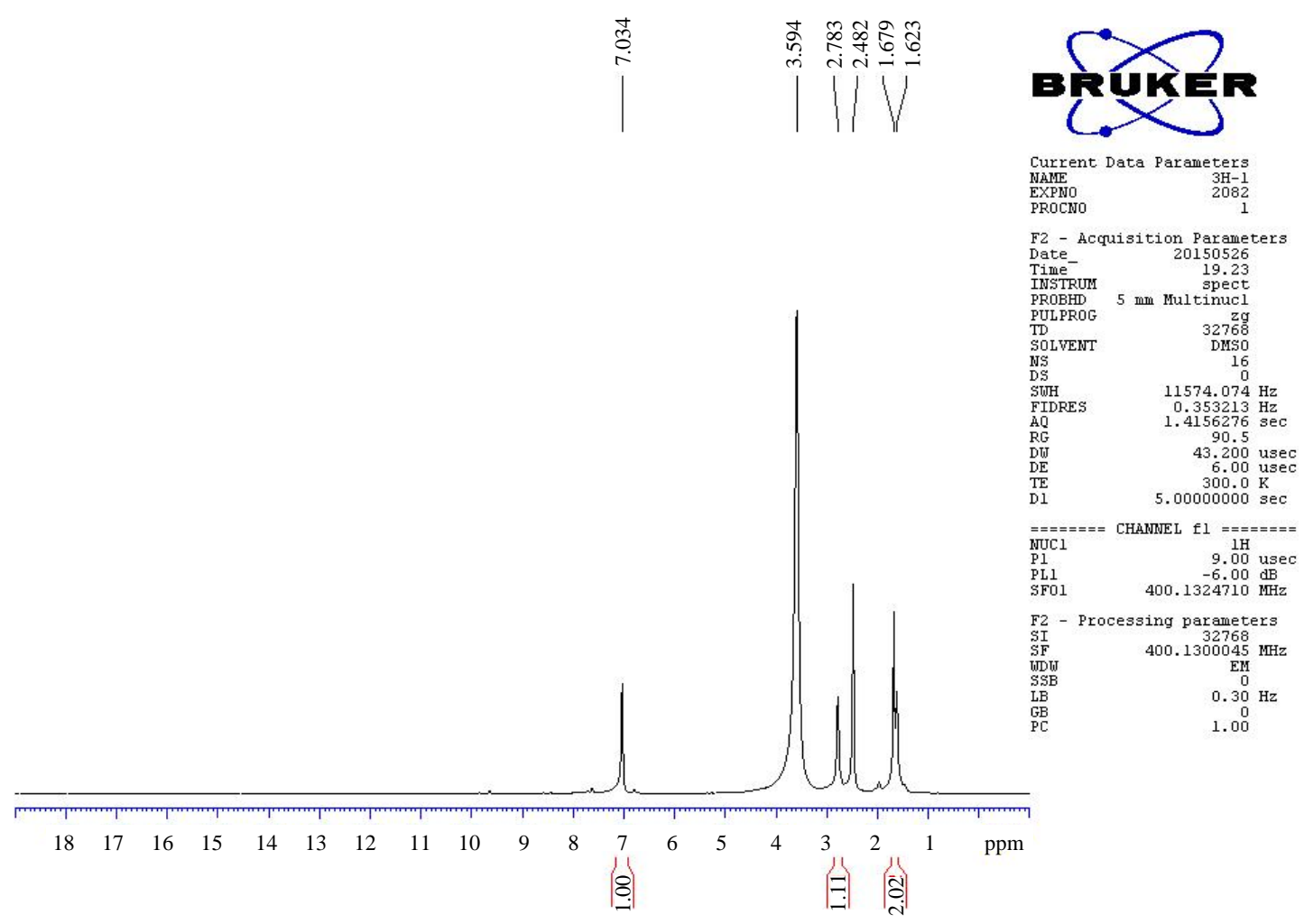

Fig. 9: H-NMR spectrum of $\left[\mathrm{C}_{6}\right]$ 


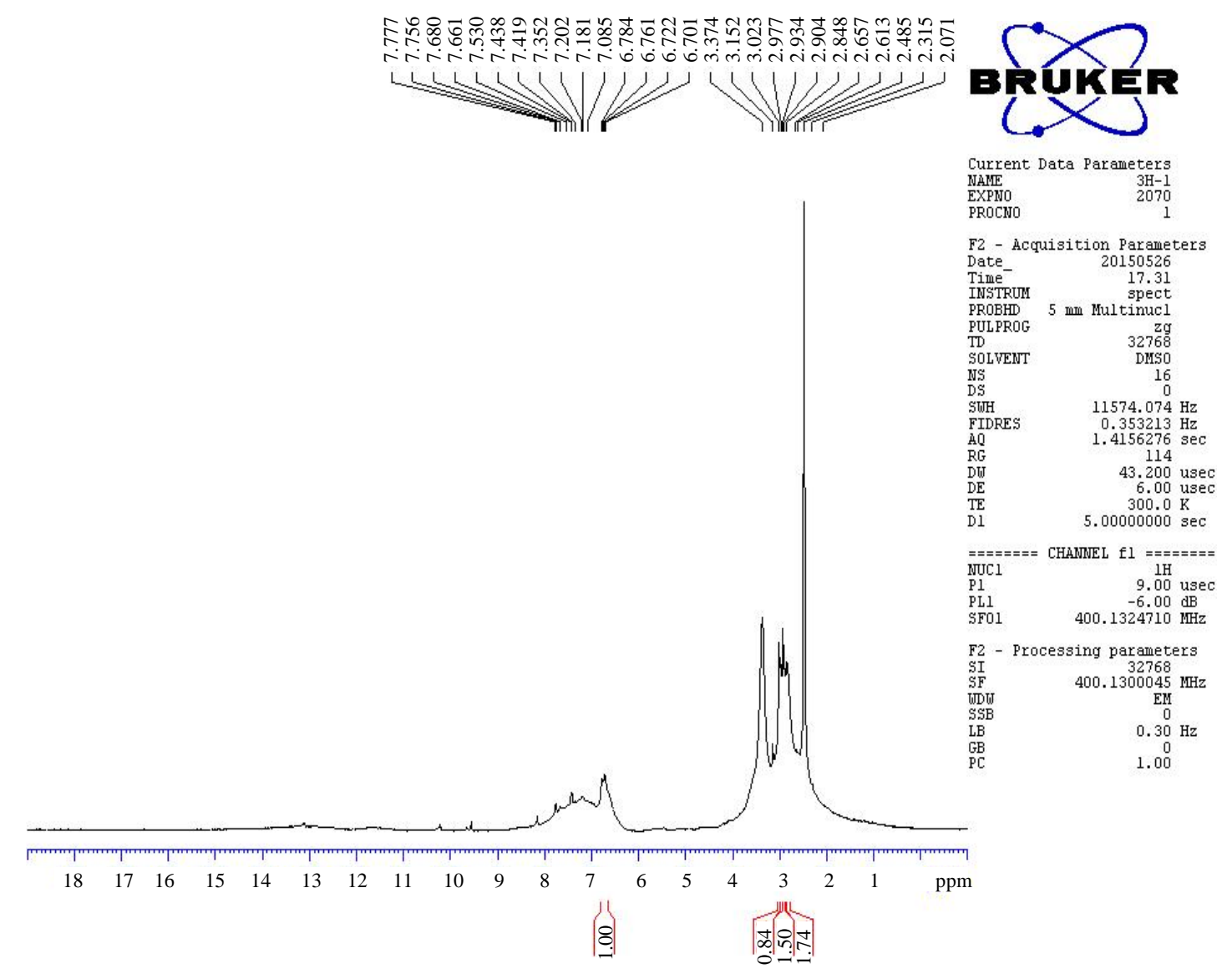

Fig. 10: H-NMR spectrum of $\left[\mathrm{C}_{10}\right]$

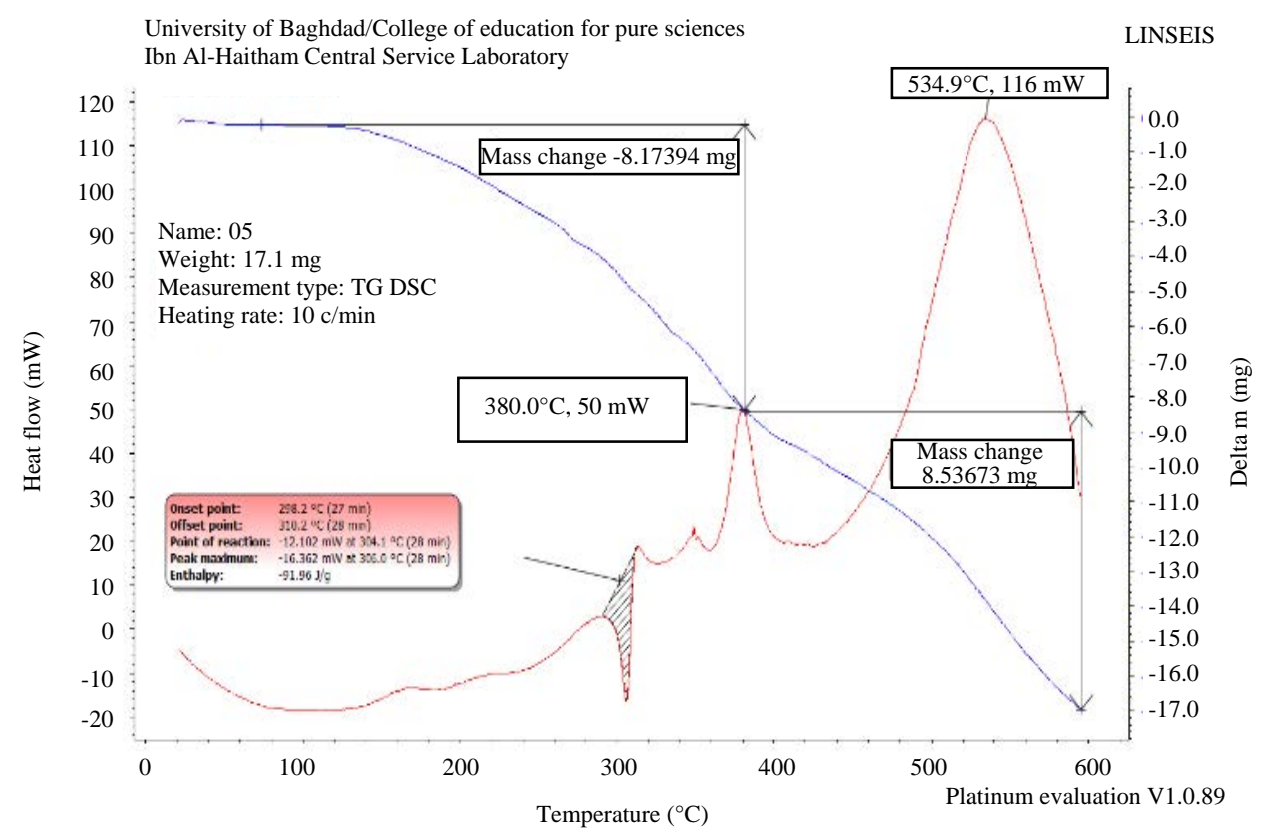

Fig. 11: TGA and DSC thermo gram of resin $\left[C_{7}\right]$ 


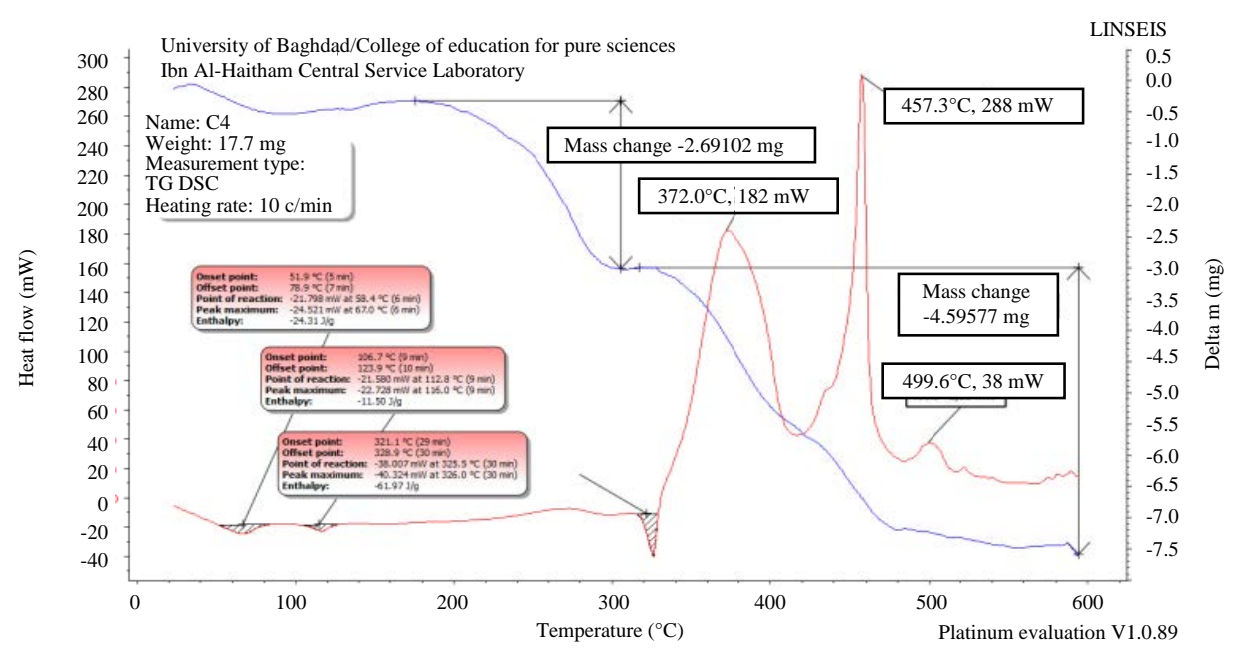

Fig. 12: TGA and DSC thermo gram of resin $\left[C_{8}\right]$

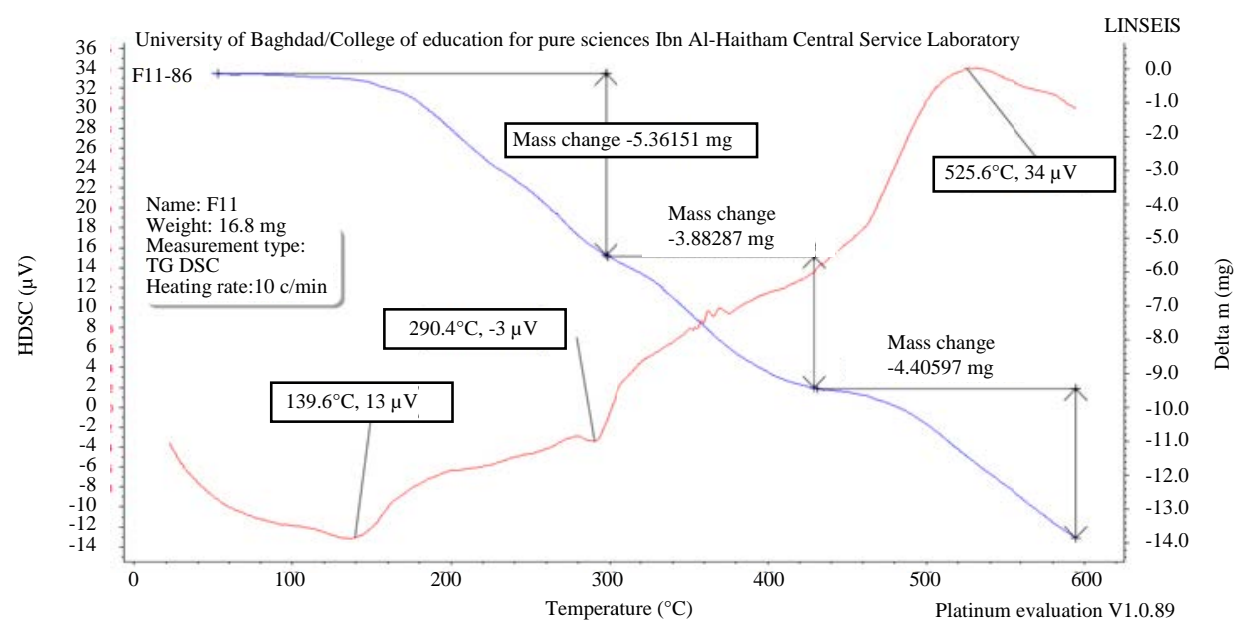

Fig. 13: TGA and DSC thermo gram of resin $\left[C_{9}\right]$

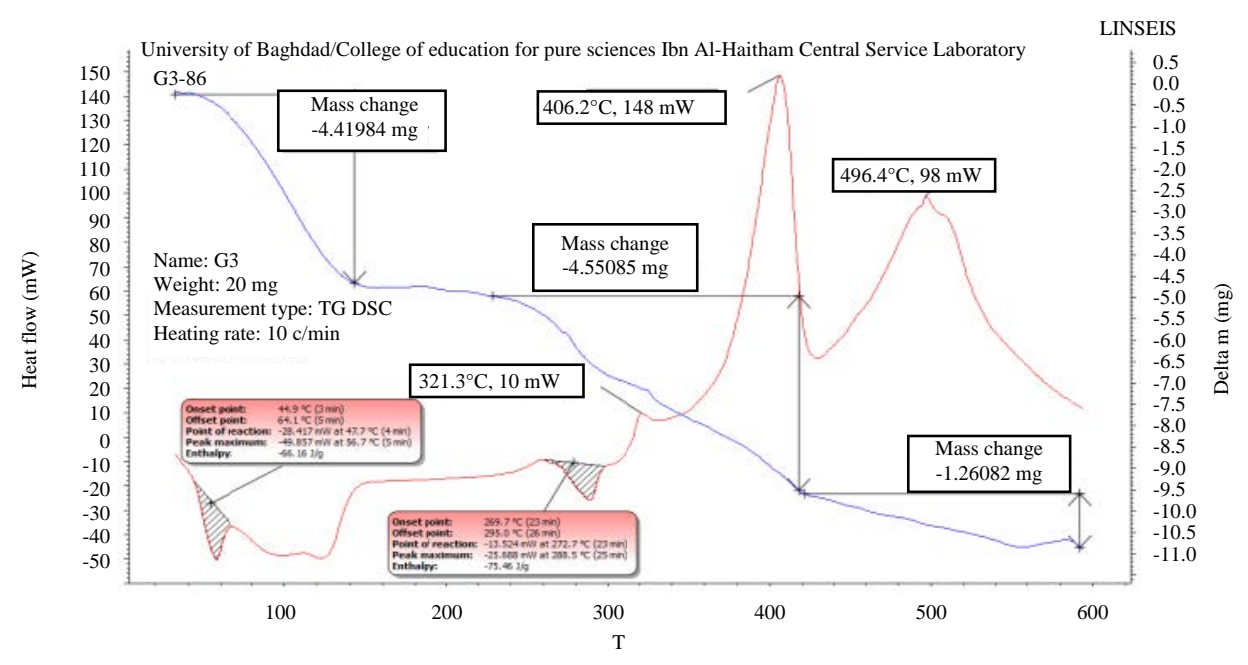

Fig. 14: TGA and DSC thermo gram of resin $\left[C_{10}\right]$ 
Where:

$\mathrm{MEPD}_{\mathrm{nc}}$ : Meaning extensor phase duration of normal control in sec

MEPD : Extensor phase duration of sample or standard (sec)

The synthesis of title compounds were started with when subsitituted aldehyde was reacted with various ketones to yield chalcones derivatives via. Claisen schmidt reaction.

Compounds have shown significant protection as (75-87), respectively. Where as $\left[\mathrm{C}_{8}, \mathrm{C}_{10}\right]$ have more protection which was even more against seizures as compound to be standard drug phenytion sodium used (80\%).

\section{CONCLUSION}

Most of the synthesized chalcone derivatives were potential lead for anticonvulsant, antioxidant, anti biological activity, respectively on the basis of observed results, it may be concluded that the substitution favors the activity. The anticonvulsant potential of chalcone derivatives is known to be influenced to a great extent by two aryl structure, i.e.

Substituent on two aryl rings of chalcone molecular and their substitution pattern. Especially, the hydroxyle substitutent is one of the key group of enhance greatly the anticonvulsant activity of chalcone derivatives mainly due to its easy conversion of phenoxy radical through the hydrogen atom transfer mechanism.

In fact the substituent are wide spread among chalcone from synthetic source there by a number of structurally diverse chalcone including phenolic have been prepared and evaluated for anti convulsant activity.

\section{REFERENCES}

Asiri, A.M. and S.A. Khan, 2012. Synthesis, characterization and In vitro antibacterial activities of macromolecules derived from Bis Chalcone. J. Heterocycl. Chem., 49: 1434-1438.

Beyhan, N., B. Kocyigit-Kaymakcioglu, S. Gumru and F. Aricioglu, 2017. Synthesis and anticonvulsant activity of some 2-pyrazolines derived from chalcones. Arabian J. Chem., 10: S2073-S2081.
Chen, W., L. Ma, A. Paul and D. Seidel, 2018. Direct $\alpha-$ $\mathrm{C}-\mathrm{H}$ bond functionalization of unprotected cyclic amines. Nat. Chem., 10: 165-169.

El-Messery, S.M., E.S.E. Habib, S.T. Al-Rashood and G.S. Hassan, 2018. Synthesis, antimicrobial, antibiofilm evaluation and molecular modelling study of new chalcone linked amines derivatives. J. Enzyme Inhib. Med. Chem., 33: 818-832.

Lahsasni, S.A., F.H. Al Korbi and N.A.A. Aljaber, 2014. Synthesis, characterization and evaluation of antioxidant activities of some novel chalcones analogues. Chem. Centr. J., 8: 1-10.

Mohammed, E.Y., 2015. Synthesis and characterization of new heterocyclic monomers and polymers vitality with studing biological activity. PhD Thesis, University of Badhdad, Badhdad, Iraq.

Muralidharan, V., A.C. Deepti and S. Raja, 2018. A review anti-inflammatory potential of substituted pyrazoline derivative synthesized from chalcones. Intl. J. Pharm. Pharm. Sci., 10: 9-14.

Ohkubo, K., K. Hirose and S. Fukuzumi, 2016. Solvent free photooxidation of alkanes by dioxygen with 2,3 dichloro 5, 6 dicyano $\mathrm{p}$ benzoquinone via photoinduced electron transfer. Chem. Asian J., 11: 2255-2259.

Pasquale, G., G.P. Romanelli, J.C. Autino, J. Garcia and E.V. Ortiz et al., 2012. Quantitative structure-activity relationships of mosquito larvicidal chalcone derivatives. J. Agric. Food Chem., 60: 692-697.

Victoria Valenzuela, D., J. Herrera Ordonez, C.L.A. Ricardo and M. Estevez, 2018. Autoacceleration in bulk free radical polymerization: Effect of Chain transfer. Macromol. Chem. Phys., Vol. 219, 10.1002/macp.201700434

Williams, D.H. and Felming, 1986. Spectroscopic Methods in Organic Chemistry. 1st Edn., University of Baghdad, Baghdad, Iraq,.

Yadav, N., S.K. Dixit, A. Bhattacharya, L.C. Mishra and M. Sharma et al., 2012. Antimalarial activity of newly synthesized chalcone derivatives In vitro. Chem. Bio. Drug Des., 80: 340-347.

Zhuang, C., W. Zhang, C. Sheng, W. Zhang and C. Xing et al., 2017. Chalcone: A privileged structure in medicinal chemistry. Chem. Rev., 117: 7762-7810. 